\title{
Infographics and Pericyclic Reactions: Multimodal Resources in Teaching of Organic Chemistry
}

\author{
Aldo Sena de Oliveira, Ana Carolina Araújo da Silva, Patrícia Bulegon Brondani, Mor-gana Aline Voigt, \\ Paola Stéfany Maass, Mauricio Raitz Junior, Eduarda Giese
}

Department of Exact Sciences and Education, Federal University of Santa Catarina, Blumenau, Brazil

Email:aldo.sena@ufsc.br

How to cite this paper: de Oliveira, A. S., da Silva, A. C. A., Brondani, P. B., Voigt, M. A., Maass, P. S., Junior, M. R., \& Giese, E. (2016). Infographics and Pericyclic Reactions: Multimodal Resources in Teaching of Organic Chemistry. Creative Education, 7, 2163-2174.

http://dx.doi.org/10.4236/ce.2016.715214

Received: July 25, 2016

Accepted: September 17, 2016

Published: September 20, 2016

Copyright $\odot 2016$ by authors and Scientific Research Publishing Inc. This work is licensed under the Creative Commons Attribution International License (CC BY 4.0).

http://creativecommons.org/licenses/by/4.0/

\begin{abstract}
In this article we report the use of infographics as a pedagogical alternative to the study of a very important theme in Chemistry Teaching. We discussed the possibility of using infographics in the classroom, as a differential to extend the learning for the construction of elaborations of multiple languages and written readings. We have created dynamical content utilizing ThingLink, an online software that enables the authors to bring life to imagens through the addition of audio, videos, social network profiles, texts and other related contents. After creating a free account within the service, the user may upload a base image and attach the complementary content in a very simple manner, without the need of knowledge of advanced programming techniques. The approach makes use of multimodal modes that enhance learning and is in line with the development of proposals for education in contemporary times.
\end{abstract}

\section{Keywords}

Infographic, Chemistry Teaching, Multimodality, Pericyclic Reactions

\section{Semiotic and the Symbolic Representation}

The work by Hodge and Kress (1988) marks the beginning of the Social Semiotics field. It is argued by the authors that social semiotics is related to human semiosis as a social phenomenon with regards to its origins, functions, context and effects. As a consequence, we can infer that social constructionism involves meaning-making processes, which include the meanings socially constructed by the means of semiotic forms, texts and practices of all kinds throughout all the history of mankind.

Laburu and Silva (2011) have argued that semiotics offers new and diverse perspectives for recent and fertile investigation fields, which might be translated to concrete procedures for a better alignment between teaching and learning, such that the former 
serves the latter, yielding pedagogical orientation for daily class-room practices.

In spite of this contemporary emphasis on the teaching learning process, little is still known about the way in which meaning is constructed in classrooms from semiotic resources in Science lectures.

Semiotic theory includes a variety of signs, symbols and rules available in a given culture in interaction with its own subjects (Perales Palacios, 2006). The image, from a semiotic point of view, is considered as a sign with many signs, which shows the relationship between the signs and their meanings. Within the teaching and learning environments there are static images (photographs, drawings, illustrations, diagrams, graphs, etc.) and dynamical images (infographics, simulations, videos, animations, etc.) (Perales Palacios, 2006).

\section{Infographics}

In this work, infographics are understood as a text containing the information, associating the words and the image. They may be considered a type of resource that explicit themes in a dynamical fashion and express in-formation utilizing a clearer and more objective language.

Infographics are a creation of contemporary journalism, which gained notoriety during the XIXth century as graphical information established their acting scene. However, their expression in verbal and visual codes dates from the birth of the press, when texts were mixed to xylography and lithography techniques. Photography, an important element in the construction of infographics, was utilized only in 1885 for the first time in printed newspapers.

Just in the 1970s, color printing became widely available for the written press and only in the 1980s computers gained popularity inside newsrooms, with the appearance of the first graphical editing software (Velho, 2009). It was only in the end of the last century, in what is now called "era of the technological journalism", that journalistic language has achieved a high degree of technical quality for images.

The presentation form of infographics as a symbolic component of great visual appeal is one of its key characteristics. It persuades the reader through its appearance and textual clarity. It is a form of representing technical information such as numbers, mechanisms and/or statistics, which must be, above all, appealing and transmitted to the reader in a short amount of time and space. It is usually utilized in Health or Science and Technology sections, in which technical data are more commonly present. It appeals to a new generation of readers, which is mostly visual and desires to understand everything in a practical and swift manner. Studies have shown that the first item read in newspapers are the titles, followed by infographics, which, many times, are the only item consulted in an article (Caixeta, 2005).

The infographic is an iconic-verbal text, i.e., composed by verbal elements associated to graphical information (images, maps, photography, graphics, etc.), which is capable of meeting the needs of information. The main characteristics of the infographic genre are: 1) it appreciates visibility, utilizing titles and illustrations directly related to the 
subject to appeal the reader; 2) it is a type of text that requires legibility, in which information is distributed in small and fragmented text blocks, with many possible reading entry points; 3 ) it presents a certain degree of emotion, resorting to a variety of colors and a colloquial language; 4) it possesses a high degree of seriousness, utilizing specific images and vocabulary and exploring precise sources and statistics related to the information (Foschiera et al., 2014).

The basic structure of an infographic is composed by a title, text, a body and font, which aim at the construction of information through a good narrative (Borrás \& $\mathrm{Ca}$ ritá, 2000). Infographics were a result of new means to publish information arising from technological development, which incorporate other genres and semiotic systems. It was pointed by Marcuschi (2006) that genres develop in a dynamical way and new genres appear as branches of others, following the necessities or new technologies, such as the telephone, radio, television and the internet.

Amaral (2009) considers four generations in the evolution of infographics:

1) The first generation was organized in a linear form;

2) The second generation started to utilize hyperlinks and animations;

3) The third generation coincides with the emergence of the first multimedia resources;

4) The fourth generation (the current one) is identified by the use of databases and interactivity provided by Web 2.0 (see Figure 1). This last generation transforms infographics in tools that can be utilized in multiple contexts.

The importance of these elements, mainly the relationship of involvement they must maintain within an info-graphical model, allow for the information to be very well expressed and understood by the reader.

Therefore, an infographic is a tool of great applicability in the field of education,

Generation and characteristics of infographics

Fourth generation: infographics set of Database
Technology Mainly use interactivity and personalization
content.

Similar products

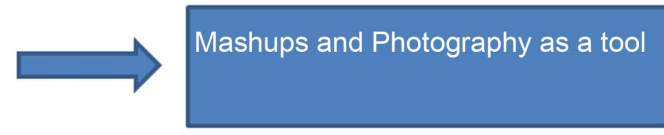

Third Generation: Specific language to the middle. It uses some web features, especially the multimedia

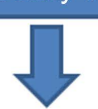

Second generation: use of links and animation, but with the language of print.

\section{News game}

\section{$\Longrightarrow$ Multimedia reporting}

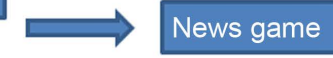

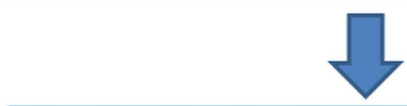

First generation: infographics with straightforward language without innovation with respect to the printed

\section{Illustrated graph}

Figure 1. Generations and characteristics of infographics (Amaral, 2009, adapted). 
especially when it harvests the power of technological developments and the possibility of widespread permanent access to the content from a variety of mobile devices.

With the objective of equalizing contemporary educational practices, developed within the multiplicity of technological resources, a restructuring of lecturing activities is observed. This restructuring is based in novel didactic-pedagogical proposals that utilize the full diversity of information technology resources.

In this framework, some authors (Wallace, 2002; Chen, Yu \& Chang, 2007) have demonstrated the use of information technology resources as a new paradigm of teaching learning, making viable a resource for educational innovation (Oliveira et al., 2014). The growing utilization of such resources effectively contributes to the incorporation of new methodologies (Pragnell, Roselli, \& Rossano, 2006).

One point that has received a lot of attention in discussions on the utilization of technological resources in educational proposals is the influence of such devices in the formation of subjectivity in students. It is important to stress that, from a historical perspective, there was a subjective change prior to the emergence of these devices, which has justified their creation. Once created, they might influence new processes of subject-making and enable new possibilities of meaning-making in the educational framework.

\section{Infographics as a Multimodal Text}

In recent years, the employment of different types of language has given rise to a novel type of text, which is increasingly common in daily social practices: the multimode text. Within the Multimode Theory, the meaning of a multimode text is realized by more than one semiotic code, as stressed by Kress and van Leeuwen (2006). Because of that, the act of reading should not be centered around the act of writing, since the latter constitutes an element of representation that coexists with the presence of image and of different types of information. Therefore, no signal or code should be fully understood if analyzed in an isolated manner, considering that elements complement themselves in the composition of meanings. Multimode texts are present in verbal communication, being constantly used especially by the press.

There exists a necessity of adopting in school an educational paradigm which provides a greater importance to multimodality and multiliteracy (Araújo, 2013; Dionísio, 2013). According to Kress and van Leeuwen (2006), every text can be considered as multimode, and the multimodality expressed in texts, especially the digital ones, develops new ways of communication, in which the logic of images and the logic on the screen overcome the logic of writing. In this scenario, a new esthetics can be observed and new ethics and literacy are then mandatory for working with contemporary texts composed of multiple languages, modes and semiosis (ROJO, 2012). For Kress and van Leeuwen (2001) multimodality is "the combination of semiotic modes in a semiotic event or production", as observed by Dionísio (2013) if social actions are multimode phenomena, a consequence is that spoken and written textual genres are equally multimode, given that, when speaking or writing a text at least two modes of representation 
are utilized: words and gestures, words and intonations, words and images, word and typo graphics, words and smiles, words and animations, etc.

Kress and van Leeuwen (2001) have extended the notion of multimodality beyond the text and the genre to the level of the discourse, proposing, even, a theory of multimode communication. They are interested in what can be said, in which mode and how. The authors consider that knowledge is socially built over (some) aspect of reality and is absolutely related to its mode of realization; they also argue that the discourse in realized in several modes (Kress \& Van Leeuwen, 2001).

Amongst multimode constructions, infographics, together with other forms of information visualization techniques, are increasingly important. On the one hand, these techniques have become widespread available and accepted by readers, given their constant presence in social networks and printed and digital mass circulation publications. On the other hand, these techniques are understood as good alternatives for the presentation of complex information in a short amount of space, stitching together the advantages of verbal and non-verbal languages and promoting the comprehension and acquisition of information.

\section{Pericyclic Reactions: A Brief Definition and Description of the Didactic Material}

Pericyclic reactions are among the most important topics of a College-level Organic Chemistry course. They are very important subjects in the concerted organic reactions point of view of.

Concerted reactions occur without an intermediate, with a transition state that involves both bond breaking and bond formation, although not necessarily to the same degree. Pericyclic reactions, in a more detailed way, are characterized by a continuous reorganization of electrons through cyclic transition structures. In this case the participating orbitals can maintain a bonding interaction between the reacting atoms throughout the course of the reaction. These specifics characteristics make pericyclic reactions predictable in terms of relative reactivity, and selectivity (Carey \& Sundberg, 2007).

Because of the complexity in terms of mechanisms, pericyclic reactions are one of the most difficult subjects in organic chemistry. One of the biggest problems in order to teach this subject in college-level is the lack of didactic material available.

The utilization of infographics and multimode tools to teach such complex subject can be an alternative enabling a discussion of the theoretical aspects maximizing the learning forms.

\section{Building Infographics: Methodology}

In the light of the lack of information on pericyclic reactions, mainly academic literature, and knowing the way that information are presented in order to describe this specific subject (linear texts with technical and difficult language), we have created a didactic material, which addresses theories, concepts and applications in an easy and 
clear way.

The initial proposal was based in different informational technologies which allow for the creation of interactive images that unite, in a single document, different codes, such as the image itself (static or animated), sound and text (a multimedia document). Interactive images can be manipulated and react to the interactions of the students, offering them the possibility of activating an action icon, according to their needs.

We have created dynamical content utilizing ThingLink, an online software that enables the authors to bring life to imagens through the addition of audio, videos, social network profiles, texts and other related content. After creating a free account within the service, the user may upload a base image and attach the complementary content in a very simple manner, without the need of knowledge of advanced programming techniques. In Figure 2 we show the creation platform for one interactive image in ThingLink. In this example, we have built and uploaded an infographic as the base for the material.

It is possible to include any service that generates a web link in the interactive image base. Redirection to the included services happens through a mouse click in small icons in well determined areas of the image.

Figure 3 shows the interactive infographic base image built for the composition of the pedagogical content on pericyclic reactions. We also present a visual example of how one action icon works.

The goal is that, for each activated icon, a new set of verbal and nonverbal information pieces are made available to the students, presenting diverse theoretical and applied aspects of the content in a condensed, objective and organized fashion. Infographics contribute to the preparation of objective and organized information pieces, which are visually appealing and have the potential to draw the attention of the reader
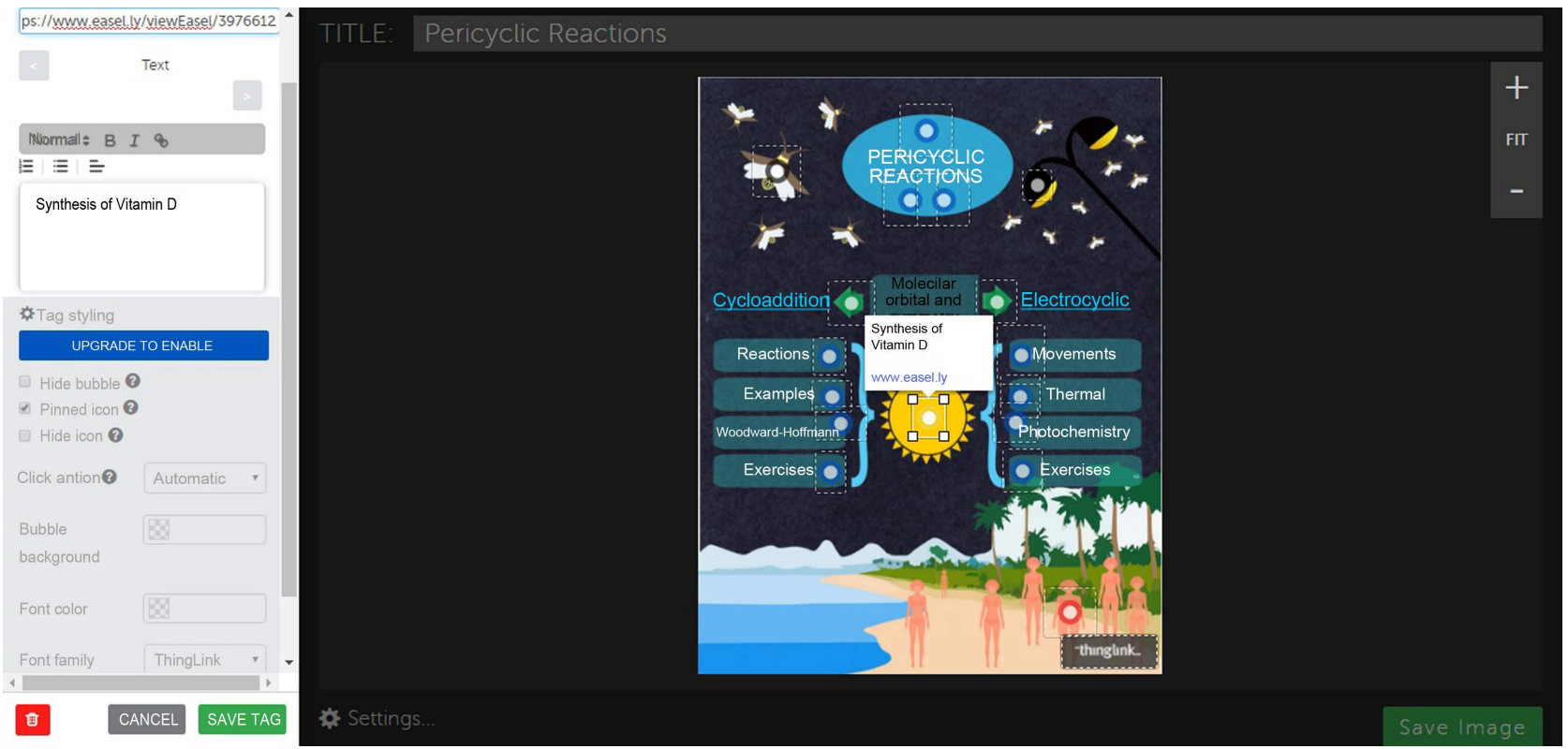

Figure 2. Creation platform for an interactive image on ThingLink. 

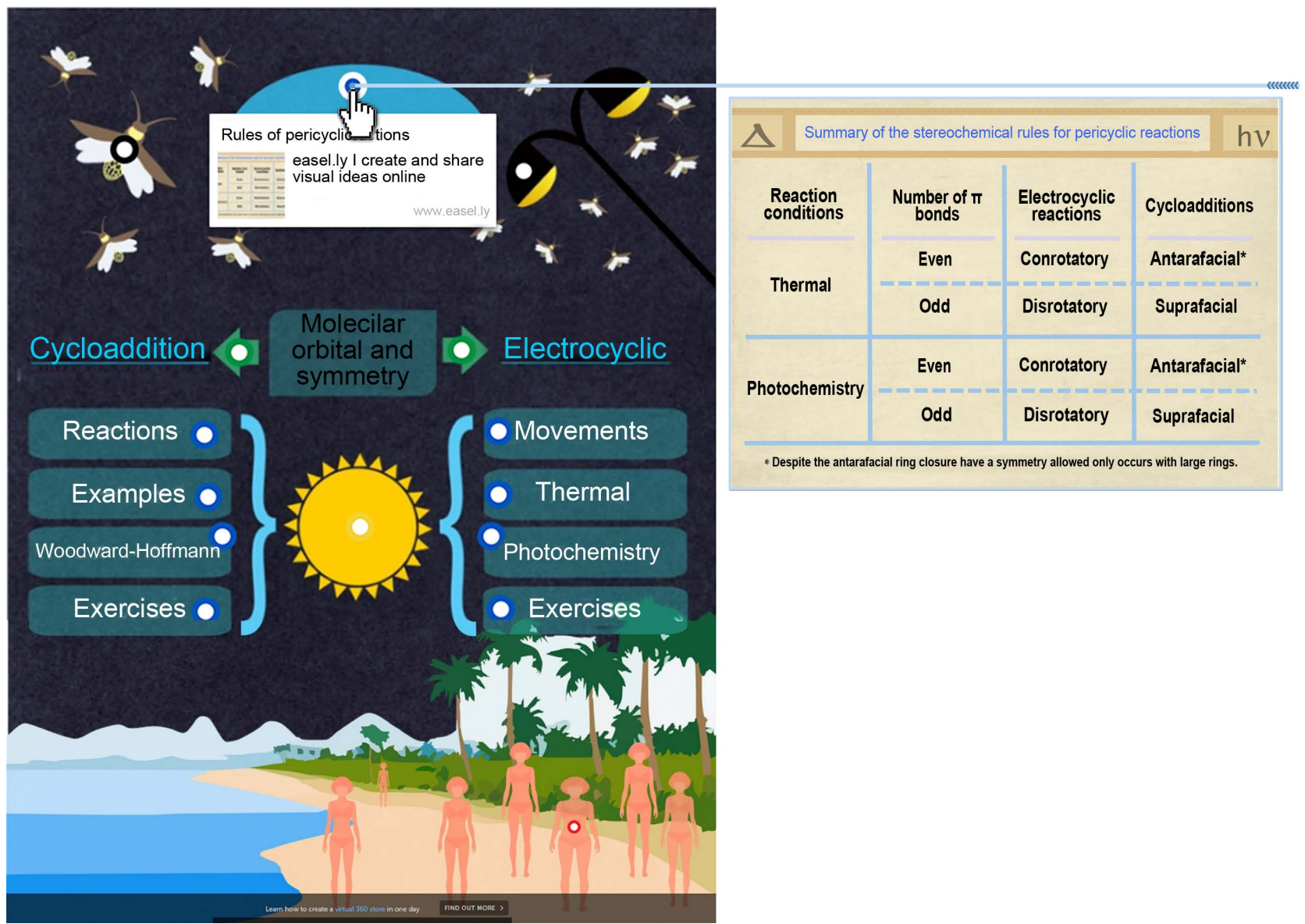

Figure 3. Base layer for the interactive infographics on pericyclic reactions, followed by an example of how action icons work.

for a deeper under-standing of the presented subject.

We propose the organization of the content in informative frames that utilize, simultaneously, text and visual elements (photos, graphics, maps or illustrations)- the infographics.

We have followed the following steps for the confection of the infographics presented in this work:

1) Selection of the content to be presented in the infographics;

2) Tests of composition, reading and comprehension of the information;

3) Input of the information in pre-designed infographic models in the online tool Easel.ly.

During the selection of the information to be presented and bibliographical research on the subject, we have also started to develop the basic structure of the infographics, aiming at creating a guide and providing theoretical and practical support from a motivational and accessible language and providing the basis for a critical discussion on pericyclic reactions.

During composition tests, we have evaluated the structure, sequence and the logical chain of the presented information. We aimed at making the information more attractive while not allowing for an incorrect interpretation of the content. 
The infographics were created utilizing Easel.ly, an online tool for the simplified and intuitive creation and sharing of infographics forms and objects in a few clicks. It works directly on the web browser and does not require the creation of an account or installation of new software in the hard drive. It has easy usability, allowing the user to choose from a large library of templates or uploading an original custom one and starting from scratch. It offers dozens of visual objects and forms that can be inserted in the final interactive image, divided in several categories (people, cards, animals, arrows, geometrical shapes, etc.), in addition to several visual effects.

In Figure 4 we present the creation platform at Easel.ly. Changing design elements is achieved by dragging icons from the tool bar and dropping them within the creation area.

The created infographics can be saved in PNG, JPG and SVG formats. They may also be published and shared in social networks through public web links. It is also possible to save the user creations on the service for future editing and publishing.

For the interactive image on pericyclic reactions, we have created eighteen infographics: one main infographics that served as the base for the interactive image, thirteen theoretical infographics and four context infographics.

The base infographics of the interactive image organizes in a methodical way the theoretical and contextual topics on pericyclic reactions that will be further developed in the content. The theoretical infographics approach the subjects through tables, schemes and summaries. The main topics considered are: general characteristics and stereochemistry of pericyclic reactions, resulting products, orbital interactions and symmetry, cycle-addition reactions: definitions, examples, the Woodward-Hoffmann rule and exercises, and electro cyclic reactions: definition, orbital movements, thermal conditions, photochemical conditions and exercises.

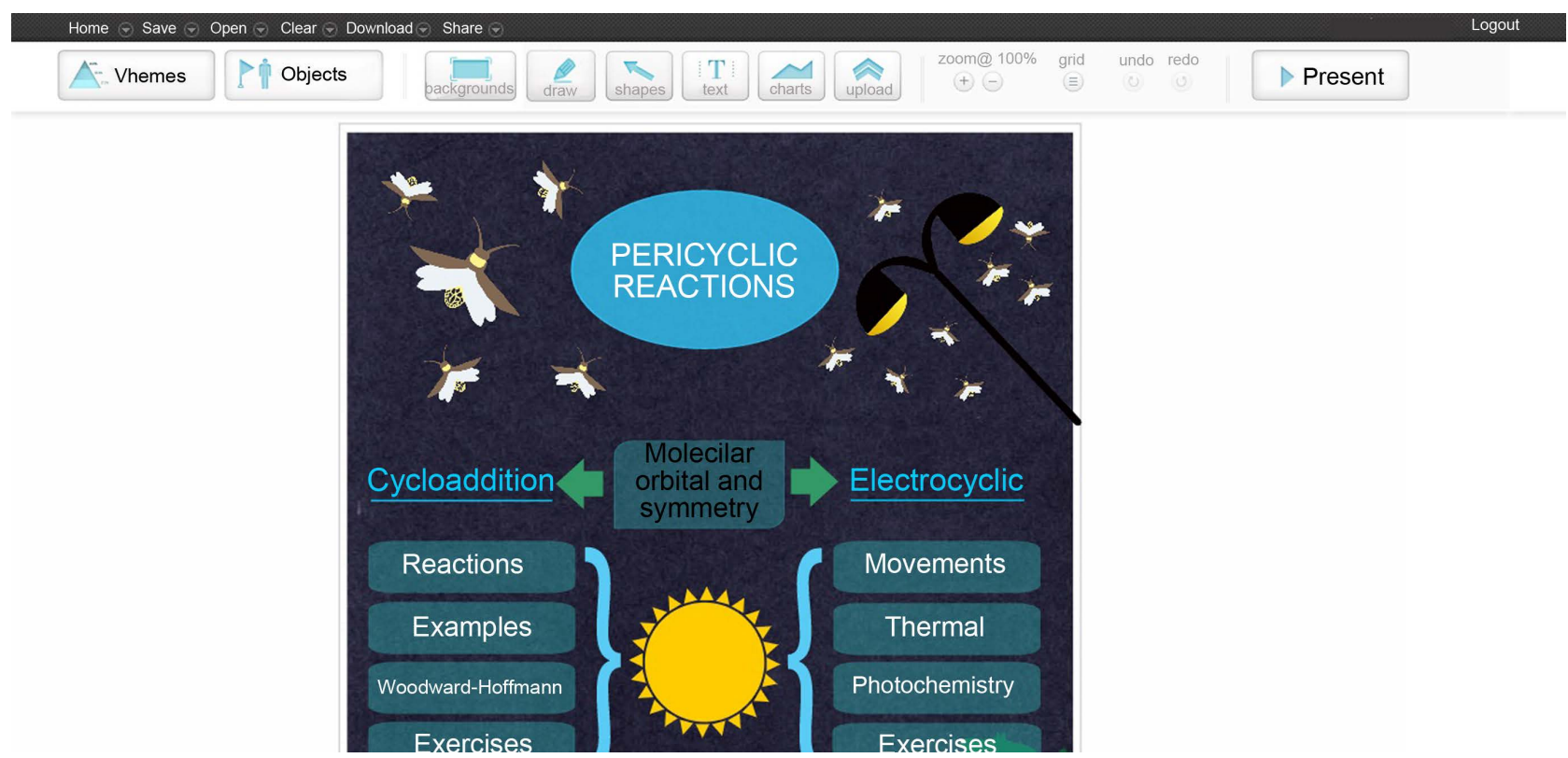

Figure 4. Toolbar and creation area in the Easel.ly tool for infographics creation. 
Figure 5 presents the working scheme of an interactive image, utilizing the base infographic as a starting point for the opening of new infographics and the expansion of information referring to each topic of the con-tent stating from action icons.

Contextualization is achieved through daily life topics that involve pericyclic reactions. Examples of these are the emission of light by fireflies, the synthesis of vitamin D in the human body, the formation of thymine dimers (which is a potential cause for skin cancer) e the phenomenon of the emission of cold light by light poles. The infographics on these topics are shown in Figure 6.

\section{Final Considerations on the Pedagogical Potential of the Utilization of Infographics in the Teaching of Pericyclic Reactions}

The utilization of infographics in the teaching of pericyclic reactions:

${ }^{*}$ Enables the possibility of presenting the subject in a contextualized manner;

${ }^{\star}$ Facilitates the internalization of the content through the use of rich images, allowing for new ways of thematic meaning making;

${ }^{\star}$ Enables visual literacy, forcing students to perform a deeper visual inspection of the image in order to fully comprehend important aspects of the image; the student gains a larger control over the visual resource and the learning process since he is now able to explore and revise each step of the content as many times as needed;

${ }^{*}$ Might become a powerful resource for publishing information in teaching and learning environments;
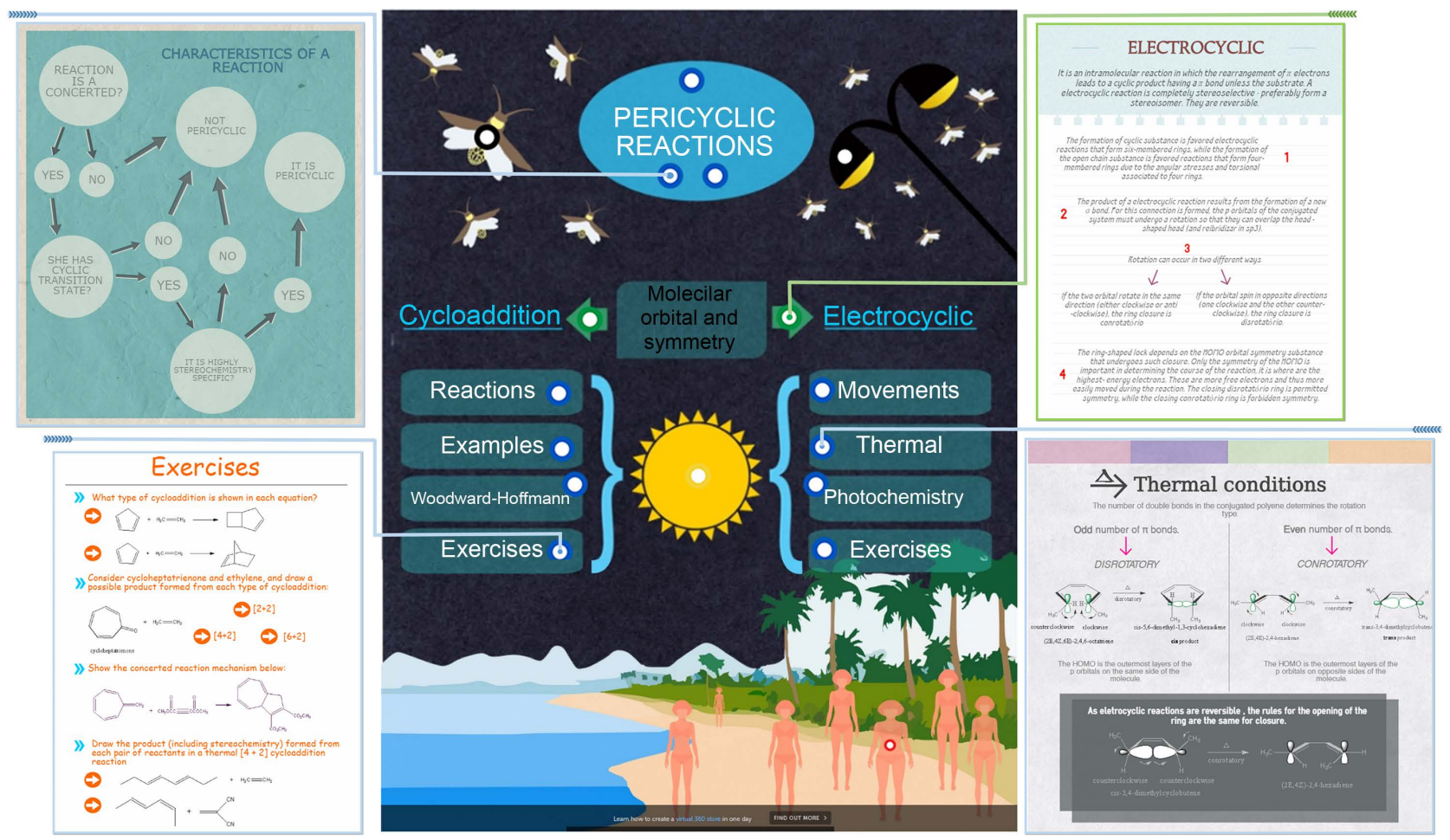

Figure 5. Working of interactive image: expansion of theoretical information in new infographics starting from action icons. 

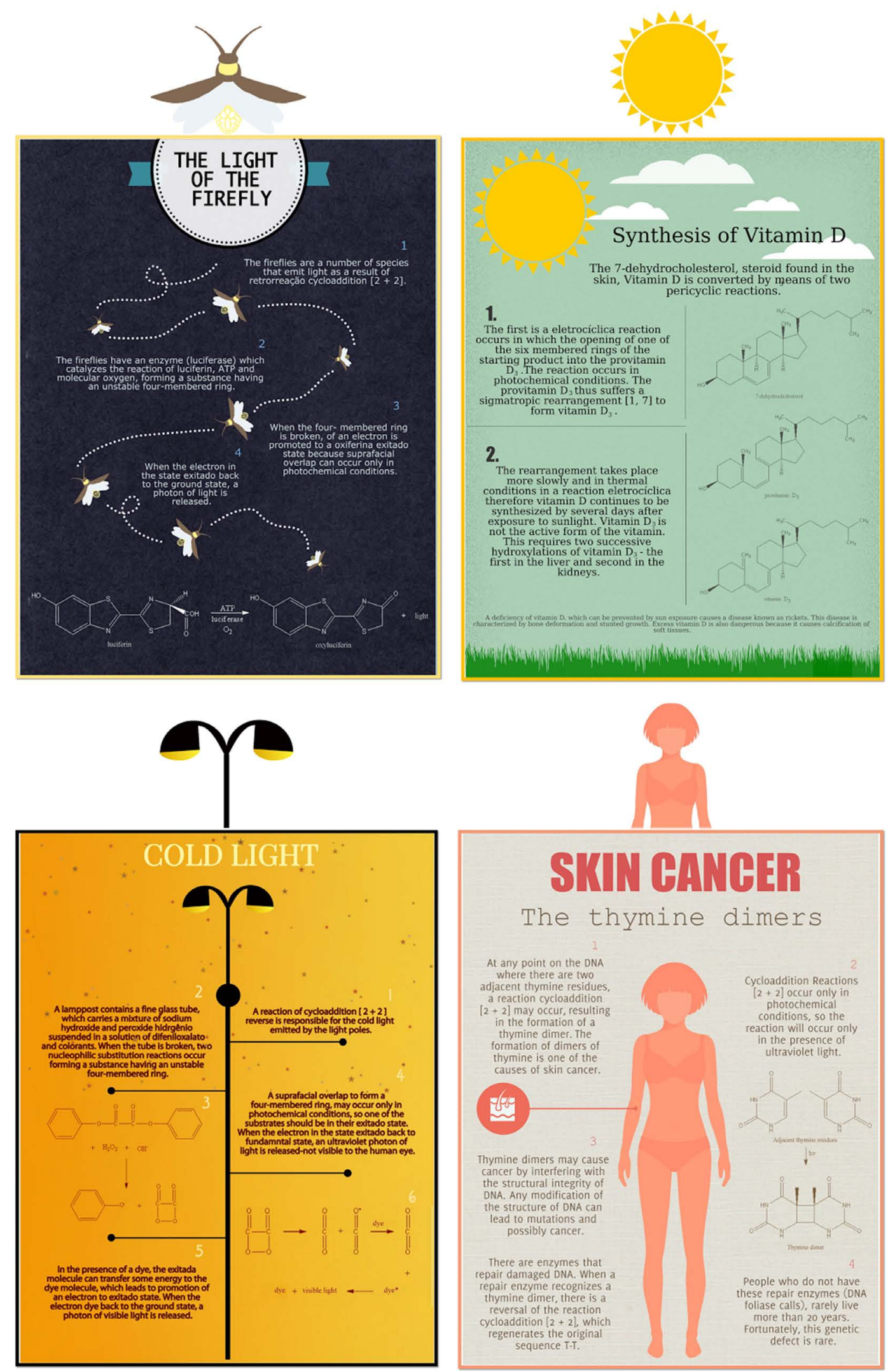

The thymine dimers

At any point on the DNA where there are two a reaction cycloaddition $[2+2]$ may occur, resultin in the formation of thymine dimer. The formation of dimers of thymine is one of the

\section{terg}

Thymine dimers may cause cancer by interfering with the structural integrity of DNA. Any modification of the structure of DNA can possibly cancer.

There are enzymes that epair damaged DNA. When a thymine dimer there is a reversal of the reaction cycloaddition $[2+2\}$ which regenerates the original

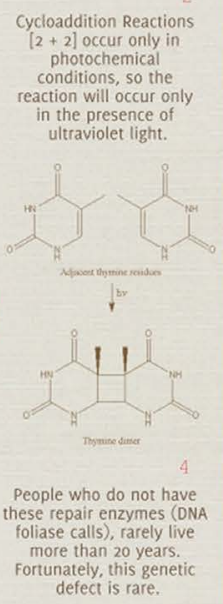

Figure 6. Infographics on the contextualization of pericyclic reactions. 
*Shows how multimode resources might facilitate the comprehension of the reaction mechanisms and enable the development of cognitive abilities as interpretation, analysis and synthesis;

${ }^{\star}$ Empowers the student to perform a non-linear navigation of the subject that might result in new discoveries;

*Permits the teacher to combine multimedia resources during the classes, aiming at improving the teaching learning process;

*Enables the student to utilize the infographics as an information source, a didactic resource, a tool for visual exploration and a support for solving exercise problems provided by the teacher.

The utilization of infographics is capable of promoting a learning process that goes beyond the abstract parameters of the content and dives into a concrete world in which the students face a consistent reality. This is a major factor for making lectures more dynamical and allows for a more detailed look at the discussed content, while giving the students the opportunity to exercise their critical and reflexive thinking.

\section{References}

Amaral, R. (2009). The Use of Infographics in Multimidialidade. National Meeting of Journalism Researchers, Universidade de São Paulo, São Paulo, 25-27 São Paulo, 25-27.

Araújo, J (2013). The Text in Digital Environments. In: C. V. Coscarelli (Org.), Readings on Reading. Steps and Space in the Classroom (Vol. 1, pp. 88-115). Belo Horizonte: Vereda.

Borrás, L., \& Caritá, M. A (2000). Infototal, Inforrelato and Infopincel. New Categories that Characterize as Informative Infographics Ferramenta. Revista Latina de Comunicación Social. http://ull.es/publicaciones/latina/argentina2000/17borras.htm

Caixeta, R. (2005). The Art to Inform. In: Publisher Brazilian Press Association (Ed.), Journalism in Practice (pp. 1-12). Rio de Janeiro.

Carey, F. A., \& Sundberg, R. J. (2007). Advanced Organic Chemistry, Part A: Structure and Mechanisms (5th ed.). New York: Springer.

Chen, H. M., Yu, C., \& Chang, C. S. (2007). E-Homebook System: A Web-Based Interactive Education Interface. Computers \& Education, 49, 160-175. http://dx.doi.org/10.1016/j.compedu.2005.05.003

Dionísio, A. P (2013). Multimodal Genres and Multiliteracy. In: C. Bunzen, \& M. Mendonça (Eds.), Multiple Languages to High School (pp. 19-42). São Paulo: Parábola Editorial.

Foschiera, S. M., de Souza, D. C., de Oliveira, T. I., \& de Andrade, F. D. (2014). Teaching Project Spanish: Infographic. Entrelinhas: Revista do curso de letras, 8. http://revistas.unisinos.br/index.php/entrelinhas/article/view/8996

Hodge, R., \& G. Kress. (1988). Social Semiotics. Cambridge: Polity

Kress, G., \& Van Leeuwen, T. (2001). Multimodal. The Modes and Media of Contemporary Communications Discourse. London: Hodder Educations.

Kress, G., \& Van Leeuwen, T. (2006). Reading Images: The Grammar of Visual Design. London/ New York: Routledge.

Laburu, C. E., \& Silva, O. H. M. (2011). Multimode and Multiple Representations: Foundations and Semiotic Perspectives for Learning Scientific Concepts. Investigações em Ensino de Ciências, 16, 7-33. 
Marcuschi, L. A. (2006). Genres: Configuration, Dynamics and Circulation. In: A. M. Karwoski, B. Gaydeczka, \& K. S. Brito (Orgs.), Genres: Reflections and Teaching (p. 232 ). Rio de Janeiro: Lucerna.

Oliveira, A. S., de Brito, M. A., Branco, N. B. C., \& de Souza, T. C. R. (2014). Shared Teaching in Distance Education: Multiple Looks for Teacher Training. Anais do Congresso Brasileiro de Ensino Superior a Distância, XI, 1998-2009.

Perales Palacios, F. J. (2006). Use (and Abuse) of the Image in Science Education. Enseñanza de las Ciencias, 24, 13-30.

Pragnell, M. V., Roselli, T., \& Rossano, V. (2006). Can a Hypermedia Cooperative Elearning Environment Stimulate Constructive Collaboration? Educational Technology \& Society, 9, 119132.

Rojo, R. (2012). Pedagogy of Multiliteracies: Cultural Diversity and Languages at School. In E. Moura (Orgs.), Multiliteracies School (pp. 11-31). São Paulo: Parábola Editorial.

Velho, A. P. M. (2009). Journalism and Infographics of the Print Media as Cultural Texts. BOCC, Communication Sciences Online Library.

Wallace, R. M. (2002). The Internet as a Site for Changing Practice: The Case of Ms. Owens. Research in Science Education, 32, 465-487. http://dx.doi.org/10.1023/A:1022477832695

\section{Submit or recommend next manuscript to SCIRP and we will provide best service} for you:

Accepting pre-submission inquiries through Email, Facebook, LinkedIn, Twitter, etc. A wide selection of journals (inclusive of 9 subjects, more than 200 journals)

Providing 24-hour high-quality service

User-friendly online submission system

Fair and swift peer-review system

Efficient typesetting and proofreading procedure

Display of the result of downloads and visits, as well as the number of cited articles

Maximum dissemination of your research work

Submit your manuscript at: http://papersubmission.scirp.org/

Or contact ce@scirp.org 